\title{
Expression of REG III and prognosis in head and neck cancer
}

\author{
TAKASHI MASUI ${ }^{1}$, ICHIRO OTA $^{1}$, ASAKO ITAYA-HIRONAKA $^{2}$, MAIKO TAKEDA $^{3}$, TAKAHIKO KASAI ${ }^{3}$, \\ AKIYO YAMAUCHI ${ }^{2}$, SUMIYO SAKURAMOTO-TSUCHIDA ${ }^{2}$, SHINJI MIKAMI ${ }^{1}$, \\ KATSUNARI YANE ${ }^{4}$, SHIN TAKASAWA ${ }^{2}$ and HIROSHI HOSOI ${ }^{1}$ \\ Departments of ${ }^{1}$ Otolaryngology-Head and Neck Surgery, ${ }^{2}$ Biochemistry and ${ }^{3}$ Diagnostic Pathology, \\ Nara Medical University, Kashihara, Nara 634-8522; ${ }^{4}$ Department of Otolaryngology, \\ Kinki University School of Medicine, Nara Hospital, Ikoma, Nara 630-0293, Japan
}

Received April 5, 2013; Accepted May 21, 2013

DOI: $10.3892 /$ or.2013.2521

\begin{abstract}
Identification of a reliable biomarker for predicting prognosis in head and neck cancers is highly desirable and has long been sought. There have been several reports that members of the regenerating gene $(R E G)$ family are highly expressed in chronic inflammation and in tumors of the digestive organs. In addition, it has been described in several reports that $R E G$ expression is associated with the progression of digestive cancers. In the present study, we evaluated the effect of $R E G$ expression on the prognosis of hypopharyngeal cancer. We investigated 37 cases with hypopharyngeal squamous cell carcinoma, determined $R E G$ mRNA expression, which is easily detected in formalin-fixed paraffin-embedded tissues using the real-time reverse transcriptase-polymerase chain reaction method, and evaluated the survival rate using the Kaplan-Meier method. According to these results, REG III mRNA expression was significantly associated with prolonged survival. Therefore, we constructed hypopharyngeal cancer cell lines transfected with REG III and assessed the cell proliferation and chemosensitivity and/or radiosensitivity in vitro. Cells transfected with REG III exhibited significantly lower cell proliferation and higher chemosensitivity and/or radiosensitivity compared with the control cells. These data suggest that REG III may be a reliable biomarker of prognosis in hypopharyngeal cancer. This is the first report concerning the association of REG III expression and the prognosis of head and neck squamous cell carcinoma including hypopharyngeal cancer.
\end{abstract}

Correspondence to: Dr Ichiro Ota, Department of OtolaryngologyHead and Neck Surgery, Nara Medical University, 840 Shijo-cho, Kashihara, Nara 634-8522, Japan

E-mail: iota@naramed-u.ac.jp

Abbreviations: REG, regenerating gene; HNSCC, head and neck squamous cell carcinoma; CRT, chemoradiotherapy; UC, ulcerative colitis; HIP/PAP, hepatocarcinoma-intestine-pancreas/pancreatitisassociated-protein; RT-PCR, reverse transcriptase-polymerase chain reaction; IL, interleukin

Key words: REG III, head and neck cancer, chemoradiosensitivity

\section{Introduction}

Head and neck squamous cell carcinoma (HNSCC) is the sixth most common type of cancer in the world and is also known for its rapid clinical progression and poor prognosis. The survival rate for HNSCC patients with advanced stage disease, particularly hypopharyngeal cancer, has improved little over the past 60 years $(1,2)$. Although extended surgery for advanced HNSCC has progressed due to the technique of microsurgery, issues concerning loss of function, aesthetic appearance and risk of various surgical complications remain unresolved. In recent years, definitive chemoradiotherapy (CRT) has become the primary treatment for advanced HNSCC in lieu of surgery, due to the advantage of preserving organ structure and function, and the equivalency in the curative effect compared with surgery. However, the survival rate of HNSCC patients has not significantly improved. Furthermore, CRT can be effective in some patients, while others show little response and experience various adverse effects, which result in the lost of opportunity for a potentially curative surgery. Therefore, we propose that it is important to differentiate whether or not each HNSCC case is chemosensitive and/or radiosensitive prior to treatment. Recently, the human papilloma virus has been identified as one of the biomarkers of chemosensitivity and/ or radiosensitivity in oropharyngeal cancers $(3,4)$. In contrast, there is no reliable marker for HNSCC in other sites.

It was previously reported that carcinogenesis is associated with chronic inflammation. Concerning digestive organs, gastritis with Helicobacter pylori infection and ulcerative colitis (UC) frequently cause gastric cancer and colorectal cancer, respectively. Recently, there have been many reports that regenerating gene $(R E G)$ expression is observed in chronic inflammation and in tumors of the digestive organs (5-9). In addition, it has been reported that REG expression is associated with progression of digestive cancers such as esophageal, gastric and colorectal cancer (10-16).

By differential screening of the regenerating pancreatic islet-derived cDNA library, $R e g$ was found and defined as a regenerating and growth factor (17-20). The Reg family belongs to the lectin superfamily and encodes five small secreted proteins $(17,21,22)$. Members of the Reg family are grouped into four subtypes: types I, II, III, and IV (23). In humans, the 
$R E G$ family is composed of five subclasses: $R E G I \alpha, R E G I \beta$, $R E G I I I$, hepatocarcinoma-intestine-pancreas/pancreatitisassociated-protein $(H I P / P A P)$ and $R E G I V(5,17,24-29)$. It has been demonstrated that they are highly expressed in a variety of inflammatory states and in tumor tissue when compared to normal tissue (17,29-31). We hypothesized that $R E G$ expression is associated with head and neck cancer derived from the oral and pharyngolaryngeal cavities, which belong to the first section of the digestive tract which are exposed to chronic inflammatory factors such as tobacco, alcohol, viral infection and the other various mechanical stress.

In the present study, we extracted RNA from formalin-fixed paraffin-embedded HNSCC tissue, specifically hypopharyngeal cancer, determined mRNA expression of the $R E G$ family gemes and evaluated the effects of $R E G$ family expression on the prognosis of hypopharyngeal cancer. The results revealed that REG III expression was significantly associated with an increased survival rate. Furthermore, we demonstrated that $R E G$ III regulated cell proliferation and chemosensitivity and/or radiosensitivity in HNSCC cells in vitro.

\section{Materials and methods}

Study population. We confirmed 37 cases with hypopharyngeal squamous cell carcinoma. All patients were treated with definitive CRT as a primary treatment between January 2000 and December 2009 at the Department of OtolaryngologyHead and Neck Surgery of Nara Medical University. The present study was approved by the Ethics Committee of Nara Medical University School of Medicine. Written informed consent for participation in the present study was obtained from each patient. The patient characteristics are listed in Table I. The patients included 34 males and 3 females, with a mean age of 68 years (range, $47-83$ years). The average period of observation was 34 months (range, 3-98 months).

Real-time reverse transcriptase-polymerase chain reaction (RT-PCR). Total RNA was isolated from each paraffin-embedded tissue upon biopsy or surgery using the RNeasy FFPE kit (Qiagen, Hilden, Germany). cDNA was then reverse transcribed from $\sim 1 \mu \mathrm{g}$ samples of total RNA using a High Capacity cDNA reverse transcription kit, with RNase inhibitor (Applied Biosystems, Foster City, CA, USA) as described $(32,33)$. Real-time RT-PCR was then carried out using the primers listed in Table II and SYBR Fast qPCR Master Mix (Kapa Biosystems, Boston, MA, USA). All PCR primers were synthesized by NGRL (Sendai, Japan). PCR was performed with an initial step of $3 \mathrm{~min}$ at $95^{\circ} \mathrm{C}$ followed by 40 cycles of $3 \mathrm{sec}$ at $95^{\circ} \mathrm{C}$ and $20 \mathrm{sec}$ at $60^{\circ} \mathrm{C}$ for $\beta$-actin, REG III and HIP/ $P A P, 40$ cycles of $3 \mathrm{sec}$ at $95^{\circ} \mathrm{C}$ and $20 \mathrm{sec}$ at $64^{\circ} \mathrm{C}$ for $R E G I \alpha$, $R E G I \beta$ and $R E G I V$. The level of target mRNA was normalized to the mRNA level of $\beta$-actin as an internal standard.

Survival analysis. We investigated the differences in prognosis between the patient group with positive $R E G$ family expression and the negative group. Overall survival rate was calculated by the Kaplan-Meier method.

Cell lines and culture. FaDu hypopharyngeal squamous cell carcinoma cells (American Type Culture Collection, Manassas,
Table I. Patient and tumor characteristics.

\begin{tabular}{lc}
\hline Characteristics & No. of patients $(\mathrm{n}=37)$ \\
\hline Gender & 34 \\
Male & 3 \\
Female & \\
Age (years) & 68 \\
Median & $47-83$ \\
Range & \\
Period of observation (months) & 34 \\
Median & $3-98$ \\
Range & \\
Tumor stage & \\
I & 4 \\
II & 6 \\
III & 6 \\
IV & 21
\end{tabular}

T classification

$\begin{array}{rr}\text { T1 } & 8 \\ \text { T2 } & 14 \\ \text { T3 } & 7 \\ \text { T4 } & 8\end{array}$

$\mathrm{N}$ classification

NO 12

$\mathrm{N} 1 \quad 7$

$\mathrm{N} 2 \quad 16$

N3 2

$\mathrm{T}$ and $\mathrm{N}$ classifications are according to the American Joint Committee on Cancer.

VA, USA) were cultured in Dulbecco's modified Eagle's medium (DMEM; Invitrogen, Grand Island, NY, USA) supplemented with $10 \%$ heat-inactivated fetal bovine serum (FBS; Gibco, Grand Island, NY, USA) and antibiotics (penicillin G/ streptomycin/amphotericin B; Gibco) in a humidified incubator at $37^{\circ} \mathrm{C}$.

Isolation of cells following stable transfection with the REG III expression vector. cDNA fragment encoding human REG III (nucleotides 56-635 of AB161037) was inserted into the pCI-neo mammalian expression vector (Promega, Madison, WI, USA). The expression vector or control vector (without insert DNA) was then introduced into FaDu cells by electroporation using Gene Pulser Xcell ${ }^{\mathrm{TM}}$ (Bio-Rad, Hercules, CA, USA) as described (15), after which the cells were cultured in DMEM supplemented with $10 \%$ FBS and $500 \mu \mathrm{g} / \mathrm{ml}$ Geneticin ${ }^{\circledR}$ (Invitrogen) for 2 weeks. We determined the REG III expression in each cell line transfected with the $R E G I I I$ or control vector using real-time RT-PCR method.

Cell proliferation assay. Cell proliferation was assessed by Cell Counting Kit- 8 (WST- 8 cleavage; Dojindo, Mashiki-machi, Japan) as described (15). Cells were seeded 
Table II. Primers for real-time RT-PCR.

\begin{tabular}{lll}
\hline Gene & & \multicolumn{1}{c}{ Primer sequence (position) } \\
\hline REG I $\alpha$ (NM_002909) & Sense & 5'-AGGAGAGTGGCACTGATGACTT-3' (nucleotides 369-390) \\
REG I $\beta$ (NM_006507) & Antisense & 5'-TAGGAGACCAGGGACCCACTG-3' (nucleotides 445-465) \\
& Sense & 5'-GCTGATCTCCTCCCTGATGTTC-3' (nucleotides 108-129) \\
REG III (AB161037) & Antisense & 5'-GGCAGCTGATTCGGGGATTA-3' (nucleotides 170-190) \\
& Sense & 5'-GAATATTCTCCCCAAACTG-3' (nucleotides 695-713) \\
HIP/PAP (NM_138937) & Antisense & 5'-GAGAAAAGCCTGAAATGAAG-3' (nucleotides 765-784) \\
& Sense & 5'-AGAGAATATTCGCTTAATTCC-3' (nucleotides 645-665) \\
REG IV (AY007243) & Antisense & 5'-AATGAAGAGACTGAAATGACA-3' (nucleotides 716-736) \\
$\beta$-actin (NM_001101) & Sense & 5'-ATCCTGGTCTGGCAAGTC-3' (nucleotides 470-487) \\
& Antisense & 5'-CGTTGCTGCTCCAAGTTA-3' (nucleotides 538-555) \\
& Sense & 5'-GCGAGAAGATGACCCAGA-3' (nucleotides 420-437) \\
\hline
\end{tabular}

RT-PCR, reverse transcriptase-polymerase chain reaction; $R E G$, regenerating gene.

in 96-well plates at an initial density of $1 \times 10^{3}$ cells/well and incubated for $0,24,48$ or $72 \mathrm{~h}$. Ten microliters of WST- 8 solution [2-(2-methoxy-4-nitrophenyl)-3-(4-nitrophenyl)-5(2,4-disulfophenyl)-2H-tetrazolium, monosodium salt] was added to each well, and the plate was incubated for another $2 \mathrm{~h}$. The absorbance of each well at $450 \mathrm{~nm}$ (reference wave length at $620 \mathrm{~nm}$ ) was determined by a Multiscan FC microplate photometer (Thermo Scientific, Waltham, MA, USA). Each measurement was repeated at least eight times on each cell line.

Radiotherapy and chemotherapy for cultured cells. Cells were exposed to 0,4 or 8 Gy irradiation using a MBR-1520R (Hitachi Co., Ibaraki, Japan) operating at $150 \mathrm{kV}$ and $20 \mathrm{~mA}$, which delivered a dose at $0.8 \mathrm{~Gy} / \mathrm{min}$. For chemotherapy, cells were treated with cisplatin (Nihon Kayaku Co., Tokyo, Japan) at a concentration of 1.0 or $10 \mu \mathrm{M}$.

In regards to chemosensitivity and/or radiosensitivity, cell viability following chemotherapy, radiotherapy or concurrent CRT in FaDu cells untransfected or transfected with REG III was evaluated using WST- 8 cleavage. Cells were seeded in 96-well plates at an initial density of $3 \times 10^{3}$ cells/well and incubated for $24 \mathrm{~h}$. For radiotherapy, they were then irradiated at 0,4 or 8 Gy. For chemotherapy, cisplatin $(0-10 \mu \mathrm{M})$ was added to each well. For concurrent therapy, the cells were irradiated (4 Gy) $2 \mathrm{~h}$ after the chemotherapy. Following incubation for an additional $48 \mathrm{~h}$, absorbance at $450 \mathrm{~nm}$ (reference wave length at $620 \mathrm{~nm}$ ) was measured as described above. Each measurement was repeated at least eight times on each cell line.

Statistical analysis. Data are presented as means \pm standard error (SE). Significant differences between groups were assessed using a log rank test for survival analysis and one-way analysis of variance (ANOVA) with the Dunnett multiple comparison test for in vitro study (StatMate III; Abacus Concepts, Berkeley, CA, USA). The differences were considered to be significant at $\mathrm{P}<0.01$.

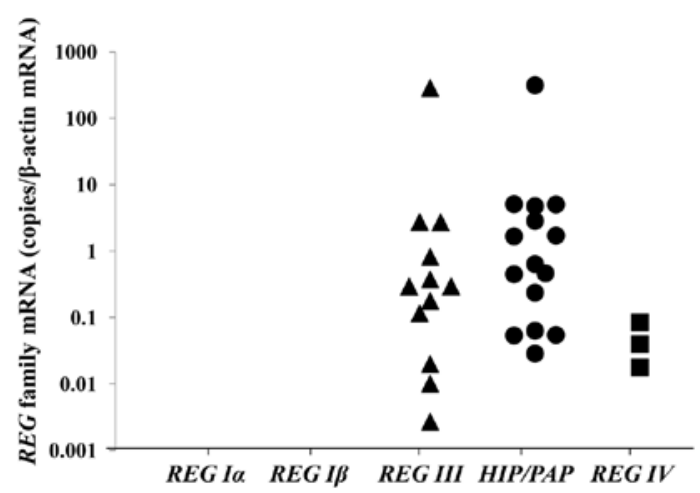

Figure 1. Number of cases expressing mRNA of each regenerating gene $(R E G)$ family member as determined by real-time reverse transcriptasepolymerase chain reaction using $\beta$-actin mRNA as an endogenous control.

\section{Results}

REG family gene expression in hypopharyngeal squamous cell carcinomas. The mRNA expression of REG family genes in each case was measured using real-time RT-PCR. No case with positive expression of REG I $\alpha$ and $R E G I \beta$ was noted, and only 3 cases were positive for $R E G I V$ expression, while there were 12 and 15 cases positive for REG III and HIP/PAP expression, respectively (Fig. 1). No positive case among the normal tissues in the hypopharyngeal area showed expression for any of the $R E G$ family genes.

Differences in survival determined by the clinical data. Each overall survival rate was calculated using the Kaplan-Meier method. The REG III expression-positive group showed long-term survival when compared to the negative group with significant difference (Fig. 2A), whereas there were no differences between groups in regards to HIP/PAP and REG IV expression (Fig. 2B and C). These data suggest that REG III expression is associated with a more favorable prognosis of hypopharyngeal squamous cell carcinoma. 

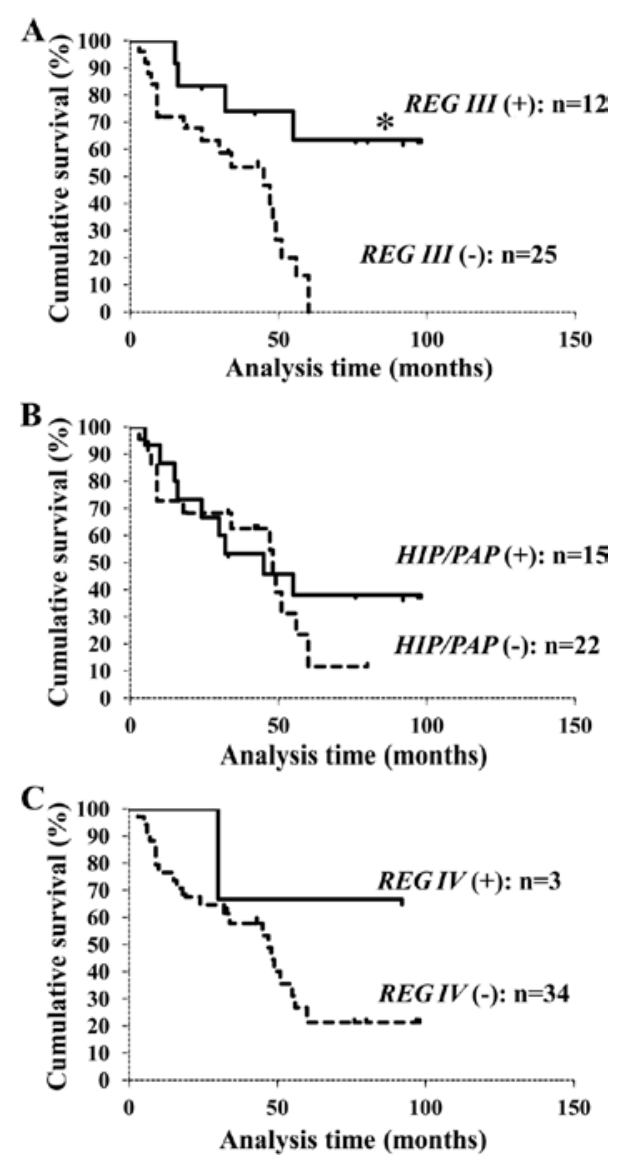

Figure 2. Effects on the survival rate of expression of regenerating gene (REG) III (A), hepatocarcinoma-intestine-pancreas/pancreatitis-associatedprotein $(H I P / P A P)(\mathrm{B})$ and $R E G I V(\mathrm{C})$. The solid line represents patients with tumors that expressed $R E G$ family (REG III, HIP/PAP and REG IV) mRNAs whereas the broken line represents patients with tumors that did not express $R E G$ family mRNAs. ${ }^{*} \mathrm{P}<0.01$ assessed as synergy by log-rank test.

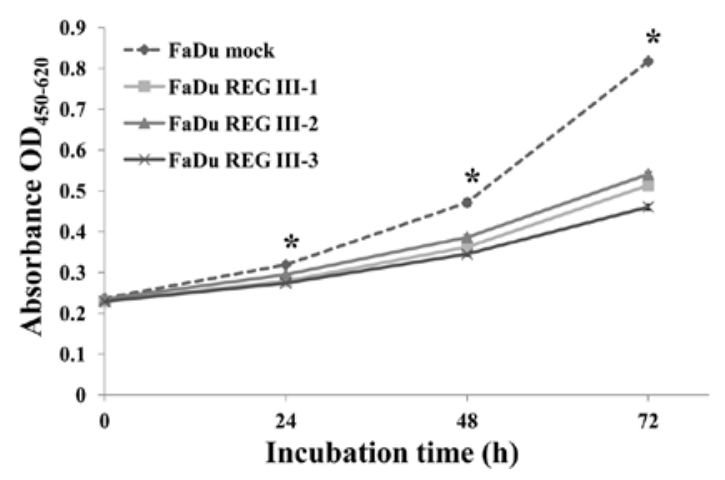

Figure 3. Differences in cell proliferation among the cell lines. FaDu hypopharyngeal squamous cell carcinoma cells were stably transfected with the regenerating gene (REG) III expression vector (FaDu REG III-1, -2 and -3 cells) or control vector (FaDu mock cells). Cell proliferation was determined by WST- 8 assay at $24 \mathrm{~h}$ intervals up to $72 \mathrm{~h}$ in each FaDu cell line. Data are shown as mean $\pm \mathrm{SE}$. "P<0.01.

REG III suppresses the growth of FaDu cells. To estimate the effect of REG III on hypopharyngeal cancer cell growth, we stably transfected $\mathrm{FaDu}$ cells, which originally express very low level of REG III mRNA, with an expression plasmid for $R E G I I I$, after which the expression of REG III mRNA was assessed (data not shown). FaDu cells transfected with the
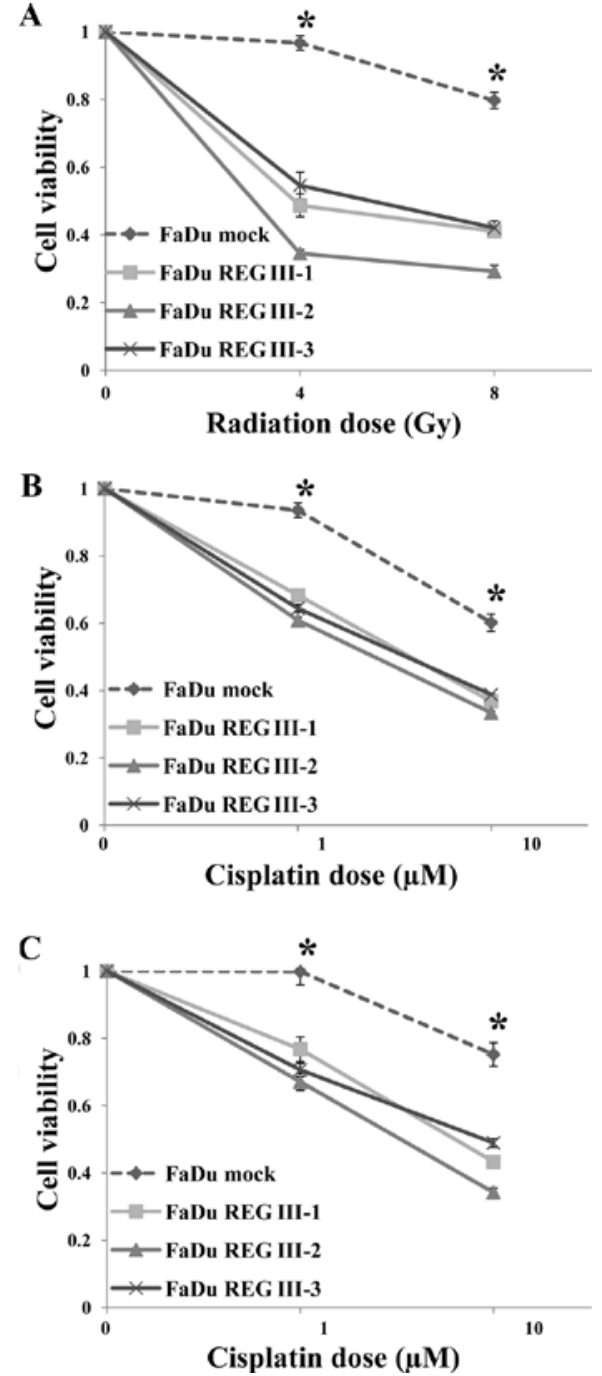

Figure 4. Enhancement of chemoradiosensitivity by regenerating gene (REG) III expression in vitro. All cells were initially incubated for $24 \mathrm{~h}$. For radiotherapy (A), cells were then irradiated at 0,4 or $8 \mathrm{~Gy}$. For chemotherapy (B) and concurrent therapy (C), cells were treated with various concentrations of cisplatin. For the concurrent therapy, $2 \mathrm{~h}$ later the cells were then irradiated at $4 \mathrm{~Gy}$. Thereafter each dish was incubated for an additional $48 \mathrm{~h}$. Cell viability was assessed using WST- 8 assay. Data are shown as mean $\pm \mathrm{SE}$. ${ }^{*} \mathrm{P}<0.01$.

REG III expression plasmid (FaDu REG III-1, -2 and -3 cells) showed higher expression of $R E G I I I$ than the cells transfected with the neomycin-resistance gene alone (FaDu mock).

In the cell proliferation assay using WST- 8 cleavage, $\mathrm{FaDu}$ REG III-1, -2 and -3 cells showed a significant decrease in growth rate when compared with the rate in the FaDu mock cells (Fig. 3).

REG III enhances the chemosensitivity and/or radiosensitivity of FaDu cells. FaDu REG III-1, -2 and -3 cells showed a significant increase in radiosensitivity at 4 and $8 \mathrm{~Gy}$ and chemosensitivity at 1.0 and $10 \mu \mathrm{M}$ cisplatin, as compared with the FaDu mock cells (Fig. 4A and B). Furthermore, chemoradiosensitivity was also significantly higher in the FaDu REG III- $1,-2$ and -3 cells at 1.0 and $10 \mu \mathrm{M}$ cisplatin (Fig. 4C). Thus, these results imply that REG III enhances the chemosensitivity and/or radiosensitivity of hypopharyngeal cancer cells. 


\section{Discussion}

Members of the Reg family are grouped into four subtypes: types I, II, III, and IV; the human $R E G$ family is composed of five subclasses: $R E G I \alpha, R E G I \beta, R E G I I I$, hepatocarcinomaintestine-pancreas/pancreatitis-associated-protein $(H I P /$ $P A P$ ) and REG IV. REG III and HIP/PAP belong to type III. The nucleotide sequence of $R E G I I I \mathrm{mRNA}$ is very similar to that of HIP/PAP mRNA (29). Although there are many reports concerning $R E G I \alpha, H I P / P A P$ and $R E G I V$, little is known regarding $R E G I I I$. $R E G I I I$ is strongly expressed in the pancreas, moderately in the testis and weakly in the heart, kidney and placenta, whereas HIP/PAP is strongly expressed in the pancreas and small intestine and weakly in hepatoma, stomach, brain and heart (29). Type III Reg proteins as well as type I Reg proteins are suggested to be induced in response to tissue inflammation such as pancreatitis $(29,34)$. However, the details of their biological function have not been fully elucidated.

In the present study, we observed many cases of hypopharyngeal cancer expressing REG III or HIP/PAP. HIP/PAP expression was not associated with a significant difference in survival, while the survival rate of patients with REG III expression was significantly prolonged when compared with that of the negative cases. In vitro, we also observe a reduction in cell growth rates and the enhancement of chemosensitivity and/or radiosensitivity in the $\mathrm{FaDu}$ cells transfected with $R E G$ III when compared with the control. These outcomes were compatible with the clinical data.

Type III Reg proteins have been suggested to be involved in cellular proliferation of intestinal, hepatic and neuronal cells $(35,36)$. High expression of type III Reg proteins has been observed in carcinomas in digestive organs and inflammatory diseases such as pancreatitis, enterocolitis and UC (29,31,37-39). Furthermore, type III proteins are also present in response to neuron damage and participate in the regeneration of neurons $(35,36,40)$. However, as the details regarding the effects of type III Reg proteins on intracellular signaling remain to be elucidated, it is still unclear how $R E G$ III functioned to enhance the chemosensitivity and/or radiosensitivity and improve the survival of patients with hypopharyngeal squamous cell carcinoma in the present study.

Several reports have shown that interleukin-6 (IL-6) and dexamethasone activate the transcription of REG I $(23,34)$. and that type III is induced by various cytokines, such as IL-6, INF- $\gamma$ and TNF- $\alpha(41,42)$. To investigate how REG III expression is regulated in HNSCC cells, we determined the expression of IL-6, -8 and -11 using real-time RT-PCR method using clinical samples in the present study. The expression of REG III and IL-11 had no correlation, while the expression of IL- 6 and IL- 8 had a positive correlation with the expression of REG III (data not shown). Although the details are still unknown, these results indicate the possibility that IL-6 and IL- 8 can become key factors to elucidate the relationship between the expression of REG III and the prognosis of hypopharyngeal cancer patients.

It has been demonstrated that Reg is highly expressed in regenerating islets and tissues of pancreatitis, whereas this expression declines when the function of the pancreas is improved $(17,37,43,44)$. Moreover, in vivo, transfection with Reg into a normal rat caused neither proliferation of $\beta$-cells nor hyperplasia of islets (19). These results suggest that there is an unknown suppressive function in vivo in contrast with the proliferative activity by Reg expression. In the present study, it was also expected that REG III may act as a suppression factor with various functions in hypopharyngeal cancer.

These data suggest that REG III, which can be easily detected in formalin-fixed paraffin-embedded tissues with RT-PCR analysis, may be a reliable biomarker of the chemosensitivity and/or radiosensitivity and prognosis of hypopharyngeal cancer. However, the biological function and cell signaling pathway of REG III require further elucidation. The critical mechanisms warrant further investigation. This is the first report concerning the association between REG III expression and the chemosensitivity and/or radiosensitivity and prognosis of HNSCC including hypopharyngeal cancer.

\section{Acknowledgements}

We are grateful to Dr Kan-ichi Nakagawara (NGRL, Sendai, Japan) for designing and providing the primers for RT-PCR. The present study is partial academic fulfillment for Thesis by T.M. of Medical Science at Nara Medical University.

\section{References}

1. Ang KK, Trotti A, Brown BW, et al: Randomized trial addressing risk features and time factors of surgery plus radiotherapy in advanced head-and-neck cancer. Int J Radiat Oncol Biol Phys 51: 571-578, 2001.

2. Ozer E, Grecula JC, Agrawal A, Rhoades CA, Young DC and Schuller DE: Long-term results of a multimodal intensification regimen for previously untreated advanced resectable squamous cell cancer of the oral cavity, oropharynx, or hypopharynx. Laryngoscope 116: 607-612, 2006.

3. Kumar B, Cordell KG, Lee JS, et al: EGFR, p16, HPV titer, $\mathrm{Bcl}-\mathrm{xL}$ and $\mathrm{p53}$, sex, and smoking as indicators of response to therapy and survival in oropharyngeal cancer. J Clin Oncol 26: 3128-3137, 2008

4. Worden FP, Kumar B, Lee JS, et al: Chemoselection as a strategy for organ preservation in advanced oropharynx cancer: response and survival positively associated with HPV16 copy number. J Clin Oncol 26: 3138-3146, 2008.

5. Watanabe T, Yonekura H, Terazono K, Yamamoto H and Okamoto H: Complete nucleotide sequence of human reg gene and its expression in normal and tumoral tissues. The reg protein, pancreatic stone protein, and pancreatic thread protein are one and the same product of the gene. J Biol Chem 265: 7432-7439, 1990.

6. Fukui H, Kinoshita Y, Maekawa T, et al: Regenerating gene protein may mediate gastric mucosal proliferation induced by hypergastrinemia in rats. Gastroenterology 115: 1483-1493, 1998.

7. Higham AD, Bishop LA, Dimaline R, et al: Mutations of RegIalpha are associated with enterochromaffin-like cell tumor development in patients with hypergastrinemia. Gastroenterology 116: 1310-1318, 1999.

8. Shinozaki S, Nakamura T, Iimura M, et al: Upregulation of Reg $1 \alpha$ and GW112 in the epithelium of inflamed colonic mucosa. Gut 48: 623-629, 2001.

9. Ose T, Kadowaki Y, Fukuhara H, et al: Reg I-knockout mice reveal its role in regulation of cell growth that is required in generation and maintenance of the villous structure of small intestine. Oncogene 26: 349-359, 2007.

10. Macadam RC, Sarela AI, Farmery SM, Robinson PA, Markham AF and Guillou PJ: Death from early colorectal cancer is predicted by the presence of transcripts of the REG gene family. Br J Cancer 83: 188-195, 2000. 
11. Violette S, Festor E, Pandrea-Vasile I, et al: Reg $I V$, a new member of the regenerating gene family, is overexpressed in colorectal carcinomas. Int J Cancer 103: 185-193, 2003.

12. Yonemura Y, Sakurai S, Yamamoto H, et al: REG gene expression is associated with the infiltrating growth of gastric carcinoma. Cancer 98: 1394-1400, 2003.

13. Dhar DK, Udagawa J, Ishihara S, et al: Expression of regenerating gene I in gastric adenocarcinomas: correlation with tumor differentiation status and patient survival. Cancer 100: 1130-1136, 2004.

14. Bishnupuri KS, Luo Q, Murmu N, Houchen CW, Anant S and Dieckgraefe BK: Reg IV activates the epidermal growth factor receptor/Akt/AP-1 signaling pathway in colon adenocarcinomas. Gastroenterology 130: 137-149, 2006.

15. Hayashi K, Motoyama S, Koyota S, et al: REG I enhances chemo- and radiosensitivity in squamous cell esophageal cancer cells. Cancer Sci 99: 2491-2495, 2008.

16. Zhou L, Zhang R, Wang L, et al: Upregulation of REG I $\alpha$ accelerates tumor progression in pancreatic cancer with diabetes. Int J Cancer 127: 1795-1803, 2010.

17. Terazono K, Yamamoto $\mathrm{H}$, Takasawa $\mathrm{S}$, et al: A novel gene activated in regenerating islets. J Biol Chem 263: 2111-2114, 1988.

18. Watanabe T, Yonemura Y, Yonekura H, et al: Pancreatic beta-cell replication and amelioration of surgical diabetes by Reg protein. Proc Natl Acad Sci USA 91: 3589-3592, 1994.

19. Unno M, Nata K, Noguchi N, et al: Production and characterization of Reg knockout mice: reduced proliferation of pancreatic beta-cells in Reg knockout mice. Diabetes 51 (Suppl 3): S478-S483, 2002.

20. Takasawa S, Ikeda T, Akiyama T, et al: Cyclin D1 activation through ATF-2 in Reg-induced pancreatic beta-cell regeneration. FEBS Lett 580: 585-591, 2006.

21. Sanchez D, Figarella C, Marchand-Pinatel S, Bruneau N and Guy-Crotte O: Preferential expression of reg I $\beta$ gene in human adult pancreas. Biochem Biophys Res Commun 284: 729-737, 2001.

22. Hervieu V, Christa L, Gouysse G, et al: HIP/PAP, a member of the reg family, is expressed in glucagon-producing enteropancreatic endocrine cells and tumors. Hum Pathol 37: 1066-1075, 2006.

23. Okamoto $\mathrm{H}$ and Takasawa S: Recent advances in the Okamoto model: the CD38-cyclic ADP-ribose signal system and the regenerating gene protein (Reg)-Reg receptor system in beta-cells Diabetes 51 (Suppl 3): S462-S473, 2002.

24. Dusetti NJ, Frigerio JM, Fox MF, Swallow DM, Dagorn JC and Iovanna JL: Molecular cloning, genomic organization, and chromosomal localization of the human pancreatitis-associated protein (PAP) gene. Genomics 19: 108-114, 1994.

25. Moriizumi S, Watanabe T, Unno M, et al: Isolation, structural determination and expression of a novel reg gene, human regI beta. Biochim Biophys Acta 1217: 199-202, 1994.

26. Lasserre C, Simon MT, Ishikawa $\mathrm{H}$, et al: Structural organization and chromosomal localization of a human gene (HIP/PAP) encoding a C-type lectin overexpressed in primary liver cancer. Eur J Biochem 224: 29-38, 1994.

27. Miyashita H, Nakagawara K, Mori M, et al: Human REG family genes are tandemly ordered in a 95-kilobase region of chromosome 2p12. FEBS Lett 377: 429-433, 1995.

28. Hartupee JC, Zhang H, Bonaldo MF, Soares MB and Dieckgraefe BK: Isolation and characterization of a cDNA encoding a novel member of the human regenerating protein family: Reg IV. Biochim Biophys Acta 1518: 287-293, 2001.
29. Nata K, Liu Y, Xu L, et al: Molecular cloning, expression and chromosomal localization of a novel human $R E G$ family gene, REG III. Gene 340: 161-170, 2004

30. Asahara M, Mushiake S, Shimada S, et al: Reg gene expression is increased in rat gastric enterochromaffin-like cells following water immersion stress. Gastroenterology 111: 45-55, 1996.

31. Ogawa H, Fukushima K, Naito H, et al: Increased expression of HIP/PAP and regenerating gene III in human inflammatory bowel disease and a murine bacterial reconstitution model. Inflamm Bowel Dis 9: 162-170, 2003.

32. Takasawa S, Kuroki M, Nata K, et al: A novel ryanodine receptor expressed in pancreatic islets by alternative splicing from type 2 ryanodine receptor gene. Biochem Biophys Res Commun 397: $140-145,2010$.

33. Ota H, Tamaki S, Itaya-Hironaka A, et al: Attenuation of glucose-induced insulin secretion by intermittent hypoxia via down-regulation of CD38. Life Sci 90: 206-211, 2012.

34. Akiyama T, Takasawa S, Nata K, et al: Activation of Reg gene, a gene for insulin-producing beta-cell regeneration: poly(ADPribose) polymerase binds Reg promoter and regulates the transcription by autopoly(ADP-ribosyl)ation. Proc Natl Acad Sci USA 98: 48-53, 2001.

35. Livesey FJ, O'Brien JA, Li M, Smith AG, Murphy LJ and Hunt SP: A Schwann cell mitogen accompanying regeneration of motor neurons. Nature 390: 614-618, 1997.

36. Namikawa K, Fukushima M, Murakami K, et al: Expression of Reg/PAP family members during motor nerve regeneration in rat. Biochem Biophys Res Commun 332: 126-134, 2005.

37. Iovanna J, Orelle B, Keim V and Dagorn JC: Messenger RNA sequence and expression of rat pancreatitis-associated protein, a lectin-related protein overexpressed during acute experimental pancreatitis. J Biol Chem 266: 24664-24669, 1991.

38. Dieckgraefe BK, Stenson WF, Korzenik JR, Swanson PE and Harrington CA: Analysis of mucosal gene expression in inflammatory bowel disease by parallel oligonucleotide arrays. Physiol Genomics 4: 1-11, 2000

39. Lawrance IC, Fiocchi C and Chakravarti S: Ulcerative colitis and Crohn's disease: distinctive gene expression profiles and novel susceptibility candidate genes. Hum Mol Genet 10: 445-456, 2001.

40. Nishimune H, Vasseur S, Wiese S, et al: Reg-2 is a motoneuron neurotrophic factor and a signalling intermediate in the CNTF survival pathway. Nat Cell Biol 2: 906-914, 2000.

41. Dusetti NJ, Ortiz EM, Mallo GV, Dagorn JC and Iovanna JL: Pancreatitis-associated protein I (PAP I), an acute phase protein induced by cytokines. Identification of two functional interleukin- 6 response elements in the rat PAP I promoter region. J Biol Chem 270: 22417-22421, 1995.

42. Ortiz EM, Dusetti NJ, Vasseur S, et al: The pancreatitisassociated protein is induced by free radicals in AR4-2J cells and confers cell resistance to apoptosis. Gastroenterology 114: 808-816, 1998.

43. Rouquier S, Verdier JM, Iovanna J, Dagorn JC and Giorgi D: Rat pancreatic stone protein messenger RNA. Abundant expression in mature exocrine cells, regulation by food content, and sequence identity with the endocrine reg transcript. J Biol Chem 266: 786-791, 1991.

44. Bluth MH, Patel SA, Dieckgraefe BK, Okamoto $H$ and Zenilman ME: Pancreatic regenerating protein (reg I) and reg I receptor mRNA are upregulated in rat pancreas after induction of acute pancreatitis. World J Gastroenterol 12: 4511-4516, 2006. 